Original Article

\title{
TIMING OF INVASION BY AFRICANIZED BEES COINCIDES WITH LOCAL EXTINCTION OF A SPECIALIZED POLLINATOR OF A RARE POPPY IN
}

\section{UTAH, USA}

\author{
Amber D. Tripodi ${ }^{1 \star}$ \\ Vincent J. Tepedino² \\ Zachary M. Portman ${ }^{3}$ \\ ${ }^{1}$ USDA-ARS-Pollinating Insects Research Unit, USA \\ 2Department of Biology, Utah State University, Logan, Utah 84322-5305, USA \\ 3Department of Biology, Utah State University, Logan, Utah 84322-5305, USA \\ Present Address- Department of Entomology, University of Minnesota, 1634 \\ Gortner Avenue, St. Paul MN 55108-1037, USA \\ *corresponding author: amberdtripodi@gmail.com \\ Received: 24 December 2018; accepted: 01 July 2019
}

\section{Abstract}

The introduction of exotic species can have profound impacts on mutualisms between native species in invaded areas. However, determining whether a new invader has impacted native species depends on accurately reconstructing the invasion timing. The arrival of Africanized honey bees (AHB) in southern Utah at some point between 1994 and 2011 has recently been implicated in the local extinction of Perdita meconis, a native specialist pollinator of an endangered poppy, Arctomecon humilis. Although AHBs were purportedly first detected in southern Utah in 2008, their presence in nearby Nevada, Arizona, and New Mexico by 1998-2001 suggests that they may have been present in Utah much earlier. We refined the arrival date of AHBs in southern Utah by using a molecular marker to determine maternal ancestry of museum specimens collected between 2000 and 2008. We found that AHBs were present in southern Utah from 2000 onwards, advancing the arrival date of this invader by at least 8 years. This lends credence to the hypothesis that AHBs played a critical role in the local extinction of $P$. meconis in Utah. This work also highlights the importance of vouchering even common species such as honey bees in museum collections to serve future research needs.

Keywords: Apis mellifera L, Arctomecon, disrupted mutualism, museum collections, molecular diagnostics, Perdita meconis

\section{NTRODUCTION}

The introduction of exotic species can have profound impacts on mutualisms in native ecosystems (Traveset \& Richardson, 2014). For example, the replacement of a native ant seed disperser by the invasive Argentine ant has greatly changed seed dispersal dynamics by plants of coastal scrublands in Australia (Rowles \& O’Dowd, 2009). There are also many examples of disruption by invasives of pollination systems with significant alterations to both pollinator and plant components of the mutualism (Traveset \& Richardson, 2014).

Recently, Portman, et al. (2018) presented evidence that implicated Africanized honey bees $(A H B)$ as the primary force that drove a population of the highly specialized bee, Perdita meconis, to extinction in Southern Utah, USA. This small, native bee is a specialist pollen collector and pollinator of poppies in the genera Arctomecon and Argemone (Griswold, 1993), including the endangered Dwarf bear poppy, Arctomecon humilis, an endemic of Washington County, Utah (USFWS, 1979). The isolated population of $P$. meconis in southern Utah disappeared between 1994 and 2012 (Tepedino, et al., 2014; Portman et al., 2018), a broad span of time that overlaps with the advance of AHBs into the region. However, assigning an important role to the AHB in the local extinction of $P$.meconis requires that we establish a convincing timeline 
of invasion; current reports claim AHBs did not arrive in Utah until 2008 (Hodgson et al., 2010; UDAF, 2017). If this invasion date is correct, then AHBs drove a specialized native bee population to extinction in a maximum of four years. Alternatively, AHBs may have been present in southern Utah much earlier than 2008 but escaped detection.

AHBs are one of the prime exemplars of rapid advance by an invasive species. Apis mellifera scutellata queens were first imported into Rio Claro, Sao Paulo, Brazil in 1956 (Moritz, Härtel, \& Neumann, 2005). Swarms from an experimental apiary escaped containment, and 26 queens, along with the paternal genes of their approximately 200 mates, escaped and spread through the landscape at an astonishing rate (Michener, 1975). The initial proliferation of AHBs throughout the New World was estimated at over $480 \mathrm{~km}$ per year in the first few decades, but slowed after they reached the United States (Visscher, Vetter, \& Baptista, 1997). This spread has been accomplished through gene flow, with current feral honey bee populations in the invaded areas consisting largely of hybrids between European and Africanized lineages (Quezada-Euán, Pérez-Castro, \& May-Itzá, 2003; Kraus, Franck, \& Vandame, 2007).

AHBs were first reported in the United States in 1990, when a feral swarm was trapped near Hidalgo, Texas; by 1993, they had reached southern New Mexico and Arizona; they were found in southern California in 1994, in southern Nevada in 1998, and by 2001 had been recorded throughout Arizona (Winston, 1992; Visscher, Vetter, \& Baptista, 1997; Hicks, 1999; Hodgson et al., 2010). However, despite monitoring efforts in the neighboring state of Utah beginning in 1994, AHBs were not reported until 2008 when the first AHB colony was detected in Cedar City in Iron County, with additional colonies detected in Washington and Kane Counties the following year (Burfitt, 2009; UDAF, 2017). Their delayed arrival in Utah is curious considering the absence of geographical barriers along its borders with Arizona and Nevada.

Our objective here is to examine arrival dates of AHBs in Utah more closely. An earlier arrival date would strengthen our contention that AHBs played a critical role in the local extinction of $P$. meconis in Utah (Portman et al., 2018). To further probe arrival dates, we used honey bee specimens obtained from museum collections. Natural history collections and molecular diagnostics are increasingly being used to refine the known distributions of insects, track changes due to climate change, document species declines, and capture information on insect movement through time (Shaffer, Fisher, \& Davidson, 1998; Lees et al., 2011; Lister \& Climate Change Research Group, 2011).

\section{MATERIAL AND METHODS}

Honey bee specimens collected in 1994-2011 from southern Utah were sought from the following national and regional collections: The National Pollinating Insect Collection at USDA-ARS Bee Biology and Systematics Laboratory (BBSL), Monte L. Bean Life Science Museum Collection at Brigham Young University (BYU), Garth and Jerri Frehner Museum of Natural History Collection at Southern Utah University (SUU), University of Utah Natural History Museum Collection (UMNH), and the Dixie State University Natural Science Museum Collection (AHBC). Specimens were shipped to Utah State University for genetic classification, and label data including plant hosts and elevation were recorded for each specimen.

Each specimen was assigned to either European or African maternal ancestry following the methods of Portman et al. (2018). In brief, a single mid-leg was removed from each specimen and DNA was extracted with a salting-out method (Sambrook \& Russell, 2001). These extracts were then subjected to a cytochromeb-based, multiplex PCR test (Szalanski \& McKern, 2007). Each sample exhibiting amplicons at both 385 and 485 bp was classified as Africanized (AHB), while those with a single amplicon at 385 bp were classified as European (EHB). This detection method is based on a mitochondrial marker, therefore it cannot detect the presence of AHB genes inherited along paternal lines. However, mitochondria are inherited intact 


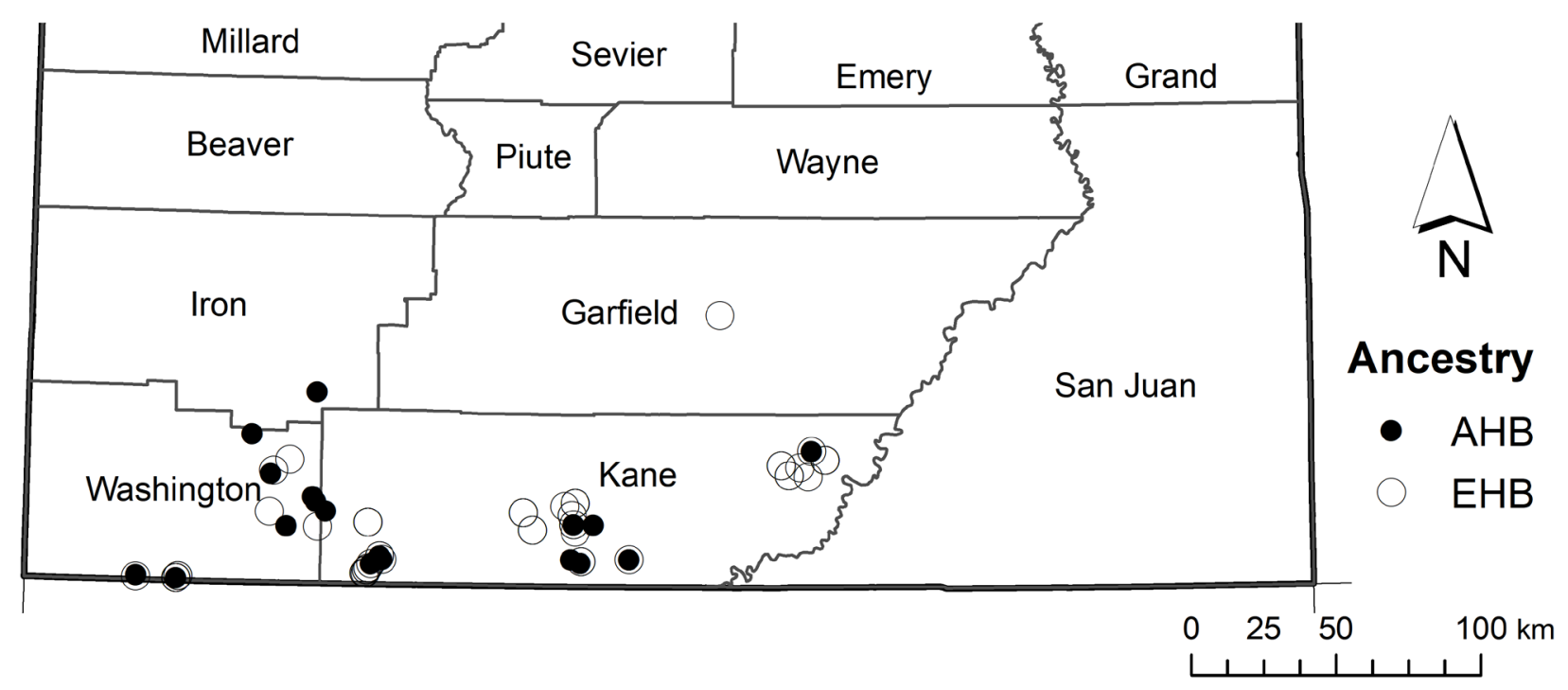

Fig. 1. Map of Apis mellifera sample locations and maternal ancestry test results throughout the counties of southern Utah. Solid circles indicate Africanized bees (AHB); open circles indicate European bees (EHB).

Honeybees mitotyped by Utah County, elevation (m) and year of collection,

Table 1.

EHB=European honeybee; AHB=Africanized honeybees

\begin{tabular}{ccccc}
\hline County & MType & Number & Elevation & Years \\
\hline Garfield & EHB & 1 & 1718 & 2002 \\
Iron & AHB & 1 & 2450 & 2003 \\
Kane & EHB & 69 & $1153-1915$ & $2000-2003$ \\
& AHB & 17 & $1326-1882$ & $2000-2001,2003$ \\
\multirow{3}{*}{ Washington } & EHB & 4 & $1264-2408$ & $2006-2007$ \\
& AHB & 6 & $1254-2107$ & $2006-2007$ \\
\hline
\end{tabular}

along the matriline, so a single marker accurately represents an individual's matriline.

\section{RESULTS}

A total of 98 worker and drone specimens collected between 2000 and 2007 were obtained from Kane, Garfield, Iron, and Washington counties in southwestern Utah (Fig. 1). Specimens were not available from San Juan, the southeastern-most county, nor for the 1994-1999 period. No specimens meeting our time and location criteria were available from the UMNH or AHBC collections.

Ninety-seven of 98 specimens were successfully mitotyped, with 24 (25\%) classified as AHB and 73 (75\%) as EHB (Tab. 1). AHBs were found in every year for which specimens were tested. In 2000, the earliest year for which honeybees were available, four of 14 Kane County specimens tested positive for Africanization; all were collected in Coral Pink Sand Dunes State Park from 1153-1886 m elevation (Tripodi et al., 2018). Over all sites and years, AHBs were found at elevations ranging from $1153-2450 \mathrm{~m}$ (Tripodi et al., 2018). Floral records were available for 54 specimens, representing 15 plant species (Tripodi et al., 2018). AHBs were found on both native and exotic plants in the region, including the protected native endemic Asclepias welshii and the ubiquitous invasive sweetclovers (Meliltus alba and M. officinalis) and saltcedars (Tamarix sp.). 


\section{DISCUSSION}

Our results clearly establish that AHBs had invaded southern Utah by 2000 and not in 2008 as previously reported (UDAF, 2017). Although we employed a mitochondrial marker that did not survey paternal contributions, the earliest samples available showed that AHB was present by 2000. The addition of nuclear data would not alter this result. Evidently invasion took place sometime after 1993: in a previous study, no specimens tested from Washington County dating 1981-1993 were Africanized (Portman et al., 2018). AHBs were present throughout adjacent Arizona by 2001 and were first reported in Clark County, Nevada in 1998 (Hicks, 1999). Clark County is $17.4 \mathrm{~km}$ from the Utah border in Washington County (UTM-12N, ArcMap v.10.3.1, ESRI, Redding, (A), and there are no obvious geographic barriers to impede the expansion of AHBs from Arizona and Nevada into Utah. Combined, these data suggest that AHBs may have invaded southern Utah as early as 1998.

Advancing the date of arrival in Utah by 8-10 years greatly strengthens our hypothesis that AHB played a critical role in the local extinction of $P$. meconis (Portman et al., 2018). To briefly recap that reconstruction, $P$. meconis was present in association with its host plant, the endangered $A$. humilis, which produces ample pollen but no nectar, at one site in Washington Co. through 1993 (Tepedino, et al., 2014). It has been absent in every census since 2012 and has been replaced by the pollen-avid AHB (Winston, 1992) which is an active and more numerous forager earlier in the morning. The AHB has also displaced the generalist native bee Eucera quadricincta which is now a rare poppy flower visitor. The period in which $P$. meconis has become extinct in Utah and $E$. quadricincta has become uncommon in Washington Co. (sometime between 1994 and 2011) coincides with the arrival of the AHB.

While the local extinction of an isolated population of $P$. meconis appears to be the only potential example of a local extinction caused by the $A H B$, there are numerous reports of honey bees, both Africanized and European, displacing native flower-visitors or changing their foraging distributions across available floral resources, and thereby reconstituting native ecosystems. For example, Santos et al. (2012), described significant changes in the structure of pollination networks in a xeric biome in Brazil following AHB invasion as did Kato et al. (1999) for the $\mathrm{EHB}$ in the Bonin Islands, and Kato and Kawakita (2004) for New Caledonia. In these and many other examples (reviewed in Geslin et al., 2017; Mallinger, Gaines-Day, \& Gratton, 2017), generalist honey bee foragers overrun the preferred floral resources of many native bees and force natives to either visit secondary or tertiary choices, if available, migrate, or expire. Although it is difficult to be certain, the sum of evidence (see Portman et al., 2018) suggests that once the $A$. humilis Beehive Dome site was invaded by pollen-hungry AHBs, $P$. meconis individuals were doomed: they could not switch hosts nor could these small, weak-flying bees migrate through the fragmented, rapidly developing, Washington Co. landscape to other poppy populations.

This example invites caution before accepting the general hypothesis that a specialist mutualism, such as the $P$. meconis- $A$. humilis association, "might be more protected against any alien entering the pollination web" (Traveset \& Richardson, 2006). While our finding hardly debases their general prediction, it does suggest that the vulnerability of specific mutualisms to invasion lies in the details. In our novel example, AHB has displaced both a highly specialized bee and an intent generalist from a globally rare, though occasionally locally abundant, plant with an uncommon reward structure in the presence of livestock grazing (Portman, Tepedino, \& Tripodi, 2018).

Early models of AHB in the USA predicted there would be climate-based limits of its northern expansion; winter conditions were expected to prevent the spread of AHB to high elevations (Taylor, 1977; Taylor \& Spivak, 1984; Winston, 1992). One model based on the natural range of $A$. m. scutellata in Africa predicted that AHBs would not venture north of the $16^{\circ} \mathrm{C}$ January 
isotherm (Taylor \& Spivak, 1984). Another model, based on physiological cold tolerance, predicted that the AHB would expand much farther north, being stymied only by areas having a maximum of 120 days with a maximum temperature of $10^{\circ} \mathrm{C}$ or less, an area that encompasses all but the northernmost portion of Utah (Southwick, Roubik, \& Williams, 1990). More recent models have incorporated the known occurrence of AHBs in the USA thus far, as well as other environmental factors like precipitation and even patterns of floral resource availability (Jarnevich et al., 2014; Gill \& Sangermano, 2016). Today, AHB are found as far north as Napa and Sacramento Counties in California (Lin et al., 2018), and at a similar latitude $\left(\sim 39^{\circ} \mathrm{N}\right)$ as far north as Emery and Grand Counties in Utah (UDAF, 2017; Cleary et al., 2018). In this study, AHB mitotypes were more heavily concentrated in the southwestern corner of Utah, which agrees well with modern models of AHB distribution (Jarnevich et al., 2014; Gill \& Sangermano, 2016). Nevertheless, the presence of AHB at high elevations such as $2450 \mathrm{~m}$ in Iron Co. in 2003 was unexpected.

Recognition of the ability of AHB to hybridize with EHB, which are better adapted to overwintering survival in cooler climates, has largely dispelled the notion that high elevations would be free of AHB. These hybrids exhibit the AHB mitotype inherited along their matrilines, and yet have inherited a number of EHB-derived genes that provide the requisite adaptations needed to survive harsh climates and long winters. Studies of AHB-EHB hybridization in the invaded neotropics have shown that honey bees in high elevation regions exhibit characteristics of both lineages. For example, the mitotypes of high elevation (2500-3500 m) honey bees in Peru are primarily AHB (56\%), yet most (42\%) exhibit intermediate phenotypes indicative of hybridization, rather than pure AHB (23\%) or EHB (35\%) morphology (Quezada-Euán, Pérez-Castro, \& May-ltzá, 2003). However, high-elevation conditions in tropical regions are not equivalent to those in the temperate region, where winters are colder and longer, and the dynamics of hybridization may differ under these selection pressures (Spivak,
1992). In central Mexico, the mitotypes of highelevation (1800-2800 m) populations of honey bees are almost exclusively AHB (96\%), yet only $59 \%$ of nuclear markers (microsatellites) are of African origin, indicating extensive hybridization not captured by mitotyping (Kraus, Franck, \& Vandame, 2007). In the temperate regions of northern Mexico, EHB mitotypes are more common (75-88\%) than AHB mitotypes, although AHB phenotypes are present in more variable proportions (14-79\%) (Domínguez-Ayala et al., 2016; Medina Flores et al., 2017). Today, the prevailing hypothesis is that AHB can move up mountain slopes as they hybridize with their EHB counterparts but extensive tests have not been conducted in temperate regions of the USA. Africanized honey bees are now common in southern Utah, with half of samples collected between 2008-2017 testing positive for AHB (Cleary et al., 2018). However, our findings of multiple AHBs at locations above $1800 \mathrm{~m}$ in Utah including one at $2450 \mathrm{~m}$ in Iron Co. in 2003 , tends to support range expansion into higher elevations of the temperate zone.

Finally, our study highlights the importance of museum collections and shows that even common species represent information that may become relevant to future research in unforeseen ways (reviewed in Suarez \& Tsutsui, 2004). Unfortunately, increasingly underfunded and understaffed museum collections often, of necessity, ignore or even discard such specimens as relatively unimportant distractions in a kind of triage operation. Hopefully, this study will help both to dispel such notions and to demonstrate the importance of funding natural history collections: although active monitoring was taking place in Utah since the 1990s (Hodgson et al., 2010), AHBs went unrecorded for at least eight years.

\section{ACKNOWLEDGMENTS}

The results of this study would have remained mere suspicion without specimens supplied by: Terry Griswold and Harold Ikerd (BBSL), Shawn Clark (BYU) supplied many critical specimens, Jacqualine Grant (SUU) found the northernmost 
and highest elevation specimen; Christy Bills (UMNH), and Marshall Topham (AHBC) searched their respective collections but to no avail. They have our sincere thanks. We also extend our appreciation to Olivia Messinger-Carril and Harold Ikerd for collection location clarifications. Dr. Tripodi contributed to this article in her personal capacity. The views expressed are her own and do not necessarily represent the views of the Agricultural Research Service or the United States Government.

\section{REFERENCES}

Burfitt, C. (2009). African bee detected in southern Utah. Retrieved 10-Dec-2018, from http://www. ag.utah.gov/animals/80-plants-and-pests/beesand-beekeeping/320-african-bee-detected-insouthern-utah.html

Cleary, D., Szalanski, A. L., Trammel, C. E., Williams, M.K., Tripodi, A. D., Downey, D. (2018). Mitochondrial DNA variation of feral honey bees (Apis mellifera L.) from Utah (USA). Journal of Apicultural Science, 62(2), 223-232. DOl: 10.2478/JAS-2018-0019

Domínguez-Ayala, R., Moo-Valle, H., May-Itzá, W. d. J., Medina-Peralta, S., Quezada-Euán, J. J. G. (2016). Stock composition of northern neotropical honey bees: mitotype and morphotype diversity in Mexico (Hymenoptera: Apidae). Apidologie, 475), 642-652. http://doi.org/10.1007/s13592-015-0414-6

Geslin, B., Gauzens, B., Baude, M., Dajoz, I., Fontaine, C., Henry, M.,... Vereecken, N. (2017). Massively introduced managed species and their consequences for plant-pollinator interactions. In Advances in Ecological Research, 57. (pp. 147-199). New York, NY: OXford Academic Press.

Gill, N. S., \& Sangermano, F. (2016). Africanized honeybee habitat suitability: a comparison between models for southern Utah and southern California. Applied Geography, 76, 14-21. http://doi.org/10.1016/j. apgeog.2016.09.002

Griswold, T. (1993). New species of Perdita (Pygoperdita) Timberlake of the $P$. californica species group
(Hymenoptera: Andrenidae). The Pan-Pacific Entomologist (USA), 69, 183-189.

Hicks, R. C. (1999). Africanized honey bees in Clark County, Nevada. In Proceedings of the 52nd Annual Meeting of the Utah Mosquito Abatement Association (pp. 1-3). Park City, Utah.

Hodgson, E. W., Stanley, C. A., Roe, A. H., \& Downey, D. (2010). Africanized honey bees. Utah Pests Fact Sheet, ENT-20-09. Retrieved 10-Dec-2018, from https:/utahpests.usu.edu/bees/africanized

Jarnevich, C. S., Esaias, W. E., Ma, P. L. A., Morisette, J. T., Nickeson, J. E., Stohlgren, T. J., ... Tan, B. (2014). Regional distribution models with lack of proximate predictors: Africanized honeybees expanding north. Diversity and Distributions, 20(2), 193-201. http:// doi.org/10.1111/ddi.12143

Kato, M., \& Kawakita, A. (2004). Plant-pollinator interactions in New Caledonia influenced by introduced honey bees. American Journal of Botany, 97(11), 1814-1827. http://doi.org/10.3732/ajb.91.11.1814

Kato, M., Shibata, A., Yasui, T., \& Nagamasu, H. (1999). Impact of introduced honeybees, Apis mellifera, upon native bee communities in the Bonin (Ogasawara) Islands. Researches on Population Ecology, 47(2), 217-228. http://doi.org/10.1007/s101440050025

Kraus, F. B., Franck, P., \& Vandame, R. (2007). Asymmetric introgression of African genes in honeybee populations (Apis mellifera L.) in Central Mexico. Heredity, 99(2), 233-240. http://doi.org/10.1038/ s..hdy.6800988

Lees, D. C., Lack, H. W., Rougerie, R., HernandezLopez, A., Raus, T., Avtzis, N. D... .. Lopez-Vaamonde, C. (2011). Tracking origins of invasive herbivores through herbaria and archival DNA: the case of the horse-chestnut leaf miner. Frontiers in Ecology and the Environment, 9(6), 322-328. http://doi. org/10.1890/100098

Lin, W., McBroome, J., Rehman, M., \& Johnson, B. R. (2018). Africanized bees extend their distribution in California. PLoS One, 13(1), e0190604. http://doi. 
org/10.1371/journal.pone.0190604

Lister, A. M., \& Climate Change Research Group. (2011). Natural history collections as sources of longterm datasets. Trends in Ecology \& Evolution, 26(4), 153-154. http://doi.org/10.1016/j.tree.2010.12.009

Mallinger, R. E., Gaines-Day, H. R., \& Gratton, C. (2017). Do managed bees have negative effects on wild bees?: A systematic review of the literature. PLoS One, 12(12), e0189268. http://doi.org/10.1371/journal.pone.0189268

Medina Flores, C. A., Guzmán Novoa, E., Hamiduzzaman, M., Aguilera Soto, J. I., Carlos, L., \& Antonio, M. (2017). Africanization of honey bees (Apis mellifera) in three climatic regions of northern Mexico. Veterinaria México OA, 2(4), 1-9. http://doi.org/10.21753/ vmoa.2.4.353

Michener, C. D. (1975). The Brazilian bee problem. Annual Review of Entomology, 20(1), 399-416. http:// doi.org/10.1146/annurev.en.20.010175.002151

Moritz, R. F. A., Härtel, S., \& Neumann, P. (2005). Global invasions of the western honeybee (Apis mellifera) and the consequences for biodiversity. Ecoscience, 12(3), 289-301. http://doi.org/10.2980/i1195-686012-3-289.1

Portman, Z. M., Tepedino, V. J., \& Tripodi, A. D. (2018). Persistence of an imperiled specialist bee and its rare host plant in a protected area. Insect Conservation and Diversity, Online 30 October, 2018, http:// doi.org/10.1111/icad.12334

Portman, Z. M., Tepedino, V. J., Tripodi, A. D., Szalanski, A. L., Durham, S. L. (2018). Local extinction of a rare plant pollinator in Southern Utah (USA) associated with invasion by Africanized honey bees. Biological Invasions, 20(3), 593-606. http://doi.org/10.1007/ s10530-017-1559-1

Quezada-Euán, J. J. G., Pérez-Castro, E. E., \& May-ltzá, W. d. J. (2003). Hybridization between European and African-derived honeybee populations (Apis mellifera) at different altitudes in Peru. Apidologie, 34(3), 217-225. http://doi.org/10.1051/apido:2003010
Rowles, A. D., \& O'Dowd, D. J. (2009). New mutualism for old: indirect disruption and direct facilitation of seed dispersal following Argentine ant invasion. Oecologia, 158(4), 709-716. http://doi.org/10.1007/ s00442-008-1171-2

Sambrook, J., \& Russell, D. W. (2001). Molecular Cloning. Cold Spring Harbor, NY: Cold Spring Harbor Laboratory Press.

Santos, G. M. d. M., Aguiar, C. M., Genini, J., Martins, C. F. Zanella, F. C., Mello, M. A. (2012). Invasive Africanized honeybees change the structure of native pollination networks in Brazil. Biological Invasions, 14(11), 2369-2378. http://doi.org/10.1007/s10530-0120235-8

Shaffer, H. B., Fisher, R. N., \& Davidson, C. (1998). The role of natural history collections in documenting species declines. Trends in Ecology \& Evolution, 13(1), 27-30. http://doi.org/10.1016/S01695347(97)01177-4

Southwick, E., Roubik, D., \& Williams, J. (1990). Comparative energy balance in groups of Africanized and European honey bees: ecological implications. Comparative Biochemistry and Physiology. A, Comparative Physiology, 971), 1-7. http://doi. org/10.1016/0300-9629(90)90713-3

Spivak, M. (1992). The relative success of Africanized and European honey-bees over a range of life-zones in Costa Rica. Journal of Applied Ecology, 29(1), 150 162. http://doi.org/10.2307/2404358

Suarez, A. V., \& Tsutsui, N. D. (2004). The value of museum collections for research and society. Bioscience, 54(1), 66-74. http://doi.org/10.1641/00063568(2004)054[0066:tvomcf]2.0.co,2

Szalanski, A. L., \& McKern, J. A. (2007). Multiplex PCRRFLP diagnostics of the Africanized honey bee (Hymenoptera : Apidae). Sociobiology, 503), 939-945.

Taylor, O. R. (1977). The past and possible future spread of Africanized honeybees in the Americas. Bee World, 58(1), 19-30. http://doi.org/10.1080/000 5772x.1977.11097632 
Taylor, O. R., \& Spivak, M. (1984). Climatic limits of tropical African honeybees in the Americas. Bee World, 65(1), 38-47. http://doi.org/10.1080/000577 2x.1984.11098769

Tepedino, V.J., Mull,J., Griswold, T. L., \& Bryant, G. (2014). Reproduction and pollination of the endangered dwarf bear-poppy Arctomecon humilis (Papaveraceae) across a quarter century: unraveling of a pollination web? Western North American Naturalist, 74(3), 311-325. http://doi.org/10.3398/064.074.0306

Traveset, A., \& Richardson, D. M. (2006). Biological invasions as disruptors of plant reproductive mutualisms. Trends in Ecology \& Evolution, 27(4), 208-216. http://doi.org/10.1016/j.tree.2006.01.006

Traveset, A., \& Richardson, D. M. (2014). Mutualistic interactions and biological invasions. Annual Review of Ecology, Evolution, and Systematics, 45, 89-113. http://doi.org/10.1146/annurev-ecolsys-120213-091857

Tripodi, A. D., Tepedino, V. J., \& Portman, Z. M. (2018). Collection data for determination of the timing of invasion by Africanized bees closely linked to local extinction of a specialized pollinator of a rare poppy in Utah. v1. Mendeley Data. http://doi. org/10.17632/8427vsmd66.1
United States Fish and Wildlife Service. (1979). Endangered and threatened wildlife and plants; determination that Arctomecon humilis is an endangered species. Federal Register, 44(216), 50 CFR Part 17, 64250-64252.

Utah Department of Agriculture and Food. (2017). Utah AHB Distribution 2017. Retrieved 03-Mar2018, from http://www.ag.utah.gov/documents/ UTAHB.pdf

Visscher, P. K., Vetter, R. S., \& Baptista, F. C. (1997). Africanized bees, 1990-1995: Initial rapid invasion has slowed in the U.S. California Agriculture, 57(1), 22-24. http://doi.org/10.3733/ca.v051n01p22

Winston, M. L. (1992). The biology and management of Africanized honey bees. Annual Review of Entomology, 371), 173-193. http://doi.org/10.1146/annurev.en.37.010192.001133 